\title{
Strategy and Implementation of Character Education in Era of Society 5.0
}

\author{
Rasmuin $^{1, *}$, Desti Widiani ${ }^{2}$ \\ ${ }^{1}$ Universitas Islam Negeri Malik Ibrahim Malang, Indonesia \\ ${ }^{2}$ Institut Agama Islam Negeri Surakarta, Indonesia \\ *Corresponding author. Email: muin@uin-malang.ac.id
}

\begin{abstract}
This article describes the importance of building character in the 5.0 society era. Era 5.0 society is a conception of a society that is literate towards Information and Communication Technology (ICT). Strengthening character education also needs to be realized, this is aimed at shaping character traits (manners) that make morals a distinctive value. The purpose of this study was to determine the strategies and ways of implementing character education in students. In addition, this study also aims to explain how ideal character education is in the face of the 5.0 society era.
\end{abstract}

Keywords: Strategy, Implementation, Character Education, Era of Society 5.0

\section{INTRODUCTION}

Indonesia has entered an era of rapid development of information and communication technology. This era is known as the era of society 5.0 where the conception of a society that is already literate towards Information and Communication Technology (ICT). The dynamics of educational transformation have developed rapidly, along with the development of technology. This can happen due to the existence of learning systems and methods that are supported by digital world technology. This development is marked by the determination of the era of globalization. The determination of globalization is marked in the industrial era 5.0. The industrial revolution era 5.0 occurred because of the impact of the 4.0 revolution [1].

Community 5.0 can be interpreted as a society in which every need must be adjusted to the standard of lifestyle (life style) of each community as well as product services that are high quality and provide a sense of comfort to everyone. One of the fundamental implications of the 5.0 industrial revolution challenge is the education element. The rapid and massive development of technology requires the education sector to be able to adapt to the digitalization of the growing education system. The challenges of the 5.0 industrial revolution era need to be carefully packaged and prepared, so that they will be in line with developments.

Era 5.0 society is a conception of a society that is literate towards Information and Communication
Technology (ICT). Some of the skills that need to be mastered for students include: creative thinking, innovative, critical thinking, communication skills and collaboration skills. Strengthening character education also needs to be realized, this is aimed at shaping character traits (manners) that make morals a distinctive value. The purpose of this study was to determine the strategies and ways of implementing character education in students. In addition, this study also aims to explain how ideal character education is in the face of the 5.0 society era.

\section{METHODS}

The approach and type of research used in this research is the library research approach, which is a research carried out to solve a problem in a problem that rests on a critical study of relevant library materials [2]. Literature study is a technique of analyzing data by conducting study studies of books, literature, notes, and reports that exist with problem solving [3].

Data sources are objects, things or people where the researcher peers, reads, or asks questions about data [4]. The data sources used are data sources that are relevant to the discussion. The data collected through this research is data that is in accordance with the research focus on the strategy and implementation of character education in era of society 5.0.

Because the data sources used in this paper are library materials, the data analysis technique applied is to read the most important parts of library materials that have 
been based on sub-chapters that have relevance to the discussion, then re-analyze in order to think systematically. Further researchers in the form of a concept or conclusion.

To analyze the data that has been collected, the approach used is "Analytical Descriptive" which describes and describes the strategy and implementation of character education in the era of society 5.0 then analyzed carefully using deductive and inductive methods.

\section{RESULT AND DISCUSSION}

\subsection{Concept of Character Education}

Character literally comes from Latin, "character" which means character, character, psychological traits, character, personality or morals [5]. Etymologically, character means mental or moral quality, moral strength. According to Abdul Majid and Dian Andayani, character education is a process of transforming the values of life to be developed in a person's personality so that they become one in that person's life behavior. In this definition there are three important ideas, namely: the process of transforming values, developing in personality and becoming one in behavior [6].

Meanwhile, according to Maragustam, character education is carving and practicing values into students through education, deposition of experience, habituation, rules, environmental engineering, and sacrifice, combined with the intrinsic values that already exist in students as a basis for thinking, behave and behave consciously and freely [7].

Character is influenced by heredity (heredity). The behavior of children is often not far from their parents. Character is also influenced by the environment. Children who are in a good environment tend to behave well, and vice versa, children who are in a bad environment will also behave badly. Character refers to a series of attitudes, behaviors, motivation (motivations), and skills (skills) [7].

Character education, moral education or character education can be said to be a process for human selfperfection, is a human effort to make himself a human being with noble character, a human being with virtue [8]. Character education, moral education or character education can be said to be a process for human selfperfection, is a human effort to $\mathrm{mP}$ Character education can also be said as education to "shape" a person's personality through character education, which results in one's real actions, namely behavior. who are good, honest, responsible, respect for others, work hard and so make him a human being with a noble character, a human being with virtue [9].

From the description above, it can be concluded that character education is an action that can form a good personality for students who are instilled with religious values, through teachers, parents and the surrounding environment.

As an effort to improve the suitability and quality of character education, the Ministry of National Education has developed a character education grand design for each path, level, and type of education unit. Grand design becomes a conceptual and operational reference for development, implementation, and assessment at every pathway and level of education.

The character configuration in the context of the totality of the psychological and socio-cultural processes is grouped into Spiritual and Emotional Development, Intellectual Devolepment, Physical and Kinesthetic Development, and Affective And Creative Development. The development and implementation of character education needs to be done by referring to the grand design [10].

The character education process is based on a psychological totality that includes all the potential of the human individual (cognitive, affective, psychomotor) and the function of the socio-cultural totality in the context of interactions in the family, educational unit, and society.

According to Lickona, character is related to moral concepts (moral knowing), moral feelings (moral feeling), and moral behavior (moral action). Based on these three components, it can be stated that good character is supported by these three components [11] The three of them have a relationship which can be seen in the chart in figure 1.

The arrow that connects each character domain with the other two domains means strengthening the relationship between these domains. Moral knowledge, moral feelings, and moral action are inseparable but they influence each other in various way [12].

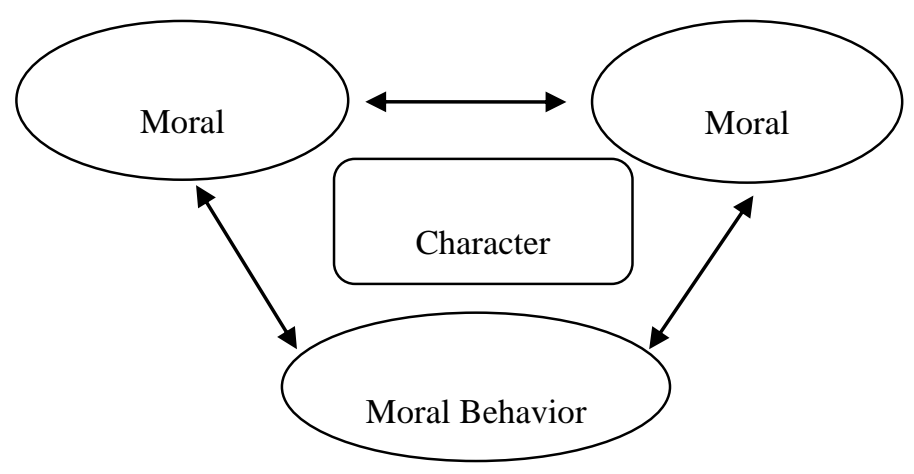

Figure 1. Aspects of Character Education 


\subsection{Character Education in Islam}

In Islam, character education is often termed morals, which has been widely explained both in the revelations of Allah SWT al-Qur'an and the hadith of Rasulallah saw. In Islam there are three main values, namely morals, manners, and exemplary. Morals refer more to duties and responsibilities other than syari'ah and Islamic teachings in general. Meanwhile, adab refers to the attitude associated with good behavior. And exemplary refers to the quality of character displayed by a Muslim who follows the example of the Prophet Muhammad [6].

Character education in Islam is different from character education that was born in the Western world, which lies in revelation as signs in Islamic character education, so that character education can be understood by religious value education. The core character values that are normative in the Islamic perspective of character education are contained in the Qur'an, while the values of character education that are practical or living are encapsulated in the person of the Prophet [6].

\subsection{Character Education Goals}

Simply put, the goal of character education can be formulated to change people for the better, in knowledge, attitudes and skills. According to E. Mulyasa, character education aims to improve the quality of educational processes and outcomes that lead to the character and noble character of students as a whole, integrated and balanced, in accordance with the competency standards of graduates in educational units. Through character education, students are expected to be able to independently improve and use their knowledge, study and personalize the values of character and noble morals so that they are manifested in daily behaviour [13].

Character education at the educational unit level leads to the formation of school culture, namely values based on behavior, traditions, daily habits, and symbols that are practiced by all school members and the surrounding community [13]. are:

In a school setting, the goals of character education

a. Strengthening and developing the values of life that are considered important and necessary so that they become the unique personality or ownership of students as the values developed.

b. Correcting the behavior of students who are not in accordance with the values developed by the school.

c. Build a harmonious connection with family and society in playing the responsibility of character education together [14].

\subsection{Character Building Stages}

Character begins to take shape when a person is a child. The first environment a person sees after birth is family. So the role of the family in character building is first and foremost. Especially the education provided by parents, especially mothers. Teachers in the family realm are both parents. So that whatever the words, actions or attitudes of the parents will be followed by the child, whether good or bad. Because when someone is a child, the dominant education is exemplary. The words and actions of the parents, which are good or bad, will directly or indirectly shape the character of the child as an individual being, a social being, a moral being, and a religious being.

The process of character building or personality consists of three levels, namely first, habituation. The aim is to form the physical aspects of the personality, or to give the ability to do and say something (rote knowledge). Examples include getting used to fasting and praying. Second, the formation of understanding, attitudes and interests. After doing the habituation, then someone is given an understanding or knowledge of the practice that is done and said. Third, the formation of a noble spirituality. This formation instills the belief that is in the pillars of faith. The result is that someone will go deeper into what is done or said, thereby increasing responsibility for what is done [15].

Character or personality education requires a simultaneous and continuous process that involves teaching aspects of knowing the good, felling the good, desiring the good, loving the good, and acting the good. Educational material is not limited to things that are affective, but also related to cognitive and psychomotor. The following is the explanation: [7]

a. Knowing the good

To form character, children not only know good things, but they must understand why they need to do this. So far they know what is good and what is bad, but they don't know the reasons.

b. Felling the good

Felling the good already planted, it will become a tremendous machine or power within a person to do good or avoid negative actions.

c. Desiring the good

This stage the child is trained to feel the effects of the good deeds he or she does.

d. Loving the good

At this stage, it tries to arouse children's love for doing good deeds.

e. Acting the good

At this stage, children are trained to do noble things. Without doing what a person already knows or feels, there is no meaning. So far, it has only been an appeal, 
even though doing something good must be trained and become part of daily life.

\subsection{Character Education Values}

Doni Koesoema emphasized that the values instilled in character education involve a variety of value compositions, including religious values, moral values, general values, and citizenship values [8]. The Ministry of National Education launched in 2010 that there are nine pillars of character education, which include:

a. Love God and all of His Creation.

b. Independence and responsibility.

c. Honesty / Trustworthiness and diplomatic. d. Respect and Courtesy.

e. Generous, like to help and mutual cooperation.

f. Trust yourself and work hard.

g. Justice and leadership.

h. Kind and humble.

i. Tolerance, peace and unity [16].

The nine pillars of character education developed in learning in Indonesia refer to the character values developed from Character First. The character education values developed in Character First are interpreted in a single first person perspective. The values and meanings of the Character First concept are listed in Table 1 below [16].

Table 1. The values of character education according to Character First.

\begin{tabular}{|c|c|c|}
\hline No & Character Value & Its meaning for me \\
\hline 1 & Alenertness & Realize what is going on around me. I have the right to respond appropriately \\
\hline 2 & Athentiveness & Show concern for someone or a task by giving my full attention \\
\hline 3 & Avaiilability & Regarding my personal programs and priorities secondary to my need to serve. \\
\hline 4 & Benevolence & Provide the basic needs of others without a motive for personal praise / gifts \\
\hline 5 & Boldness & I am sure to say or do what I think is right, right and fair \\
\hline 6 & Cautiousness & Know the importance of the right timing to get the right things done \\
\hline 7 & Compassion & Do whatever is necessary to heal the sick (both physical and heart) of others \\
\hline 8 & Contentment & Realizing true happiness, does not depend on material conditions \\
\hline 9 & Creativity & Approaching the fulfillment of a need, task, or idea with a new perspective. \\
\hline 10 & Decisiveness & $\begin{array}{l}\text { The ability to identify the key factors required for success and to be able to make difficult } \\
\text { final decisions. }\end{array}$ \\
\hline 11 & Deference & I consciously limit my freedom so that I don't hurt the feelings and feelings of others. \\
\hline 12 & Dependability & $\begin{array}{l}\text { Completing what was promised to be done even though it turned out to have to sacrifice } \\
\text { something unexpected }\end{array}$ \\
\hline 13 & Determination & Aim to accomplish the right goal at the right time, without fear of opposers \\
\hline 14 & Diligence & Risking all my energy to complete the tasks assigned to me \\
\hline 15 & Discernment & Understand all the reasons behind what happened \\
\hline 16 & Discretion & $\begin{array}{l}\text { Recognizing and avoiding words, actions and attitudes that can have unwanted } \\
\text { consequences }\end{array}$ \\
\hline 17 & Endurance & Heart strength to withstand stress and do the best \\
\hline 18 & Enthusiasm & Express enthusiasm and excitement in carrying out all duties so as to give the best effort \\
\hline 19 & Faith & $\begin{array}{l}\text { I am sure that actions based on good character will reap the best results, even though I do } \\
\text { not know what the results will be. }\end{array}$ \\
\hline 20 & Flexibility & The courage to change plans or ideas without regretting it \\
\hline 21 & Forgiveness & Erase the error log of someone who made a mistake \\
\hline 22 & Generosity & $\begin{array}{l}\text { Thriftily and carefully managing the resources he has so that I can freely give them to } \\
\text { someone who is most in need }\end{array}$ \\
\hline 23 & Gentleness & Shows calm and personal care for others \\
\hline 24 & Gratefullness & Let people know from my words or actions as they are serving me \\
\hline 25 & Honor & Respect someone because of their meaning as human beings. \\
\hline 26 & Hospitality & Cheerfully and sincerely a variety of nourishment, protection, and friendship with others \\
\hline 27 & Humanity & Acknowledging the role and service of others in my life \\
\hline 28 & Initiave & Identify and do something that really needs to be done before I am asked if I want to do it \\
\hline 29 & Joyfullness & Maintain a good attitude even in unpleasant conditions \\
\hline 30 & Justice & Taking personal responsibility for maintaining what is pure, true and true \\
\hline 31 & Loyality & Take advantage of times of adversity to show my commitment to those I serve \\
\hline 32 & Meekness & Subordinate my personal rights and expectations to my desire to serve \\
\hline 33 & Obedience & Quickly and energetically carry out the directions of those who bear me. \\
\hline
\end{tabular}




\begin{tabular}{|l|l|l|}
\hline 34 & Orderliness & Take care of myself and my surroundings in order to achieve the greatest efficiency \\
\hline 35 & Patience & Accept a difficult situation without setting a deadline or avoiding it \\
\hline 36 & Persuasiveness & Trusting that other mentally good people can guide you to the main path of truth. \\
\hline 37 & Punctually & Show self-respect in others by doing the right things at the right times \\
\hline 38 & Resourcefulness & Doing things wisely that others may never think about or ignore \\
\hline 39 & Responsibility & Knowing and doing what it is hoped I will do. \\
\hline 40 & Security & Fortify myself with things that cannot destroy or harm me. \\
\hline 41 & Self control & Resisting evil and bad desires and doing what is good. \\
\hline 42 & Sensitivity & Using all my five senses to assess the attitudes or emotions of others \\
\hline 43 & Siencerity & Firmly doing what is right with a transparent motive \\
\hline 44 & Thoroughness & $\begin{array}{l}\text { Knowing what factors could erase the effectiveness of my work or the meaningfulness of } \\
\text { my words, if ignored }\end{array}$ \\
\hline 45 & Thriftiness & Make myself or others shop something necessary \\
\hline 46 & Tolerance & Accepting other people whose maturity level is different from mine \\
\hline 47 & Thruthfulness & Build honesty for the future by accurately reporting the facts of the past \\
\hline 48 & Virtue & Superior morals occur in my life because I consistently do what is good and right \\
\hline 49 & Wisdom & Carry out the practical application of the truth in my daily life \\
\hline
\end{tabular}

There are many values of character education that educational institutions can do. The following are various values that can be identified as character education values. These values are divided into various groups, namely:

a. Values associated with Allah SWT, namely piety, faith, sincerity, and ihsan.

b. Values related to oneself, namely honesty, hard work, assertiveness, patience, resilience, cheerfulness, firmness, openness, visionary, independent, tough, courageous, responsible, disciplined and reflective.

c. Values related to other people or creatures, namely being happy to help, tolerance, smiling, generous, cooperative, communicative, calling for kindness, preventing evil, caring and fairness [14].

\subsection{Strategy and Implementation of Character Education In Era of Society 5.0}

Era 5.0 society is a conception of a society that is literate towards Information and Communication Technology (ICT). Community 5.0 can be interpreted as a society in which every need must be adjusted to the standard of lifestyle (life style) of each community as well as product services that are high quality and provide a sense of comfort to everyone. One of the fundamental implications of the 5.0 industrial revolution challenge is the education element.

The rapid and massive development of technology requires the education sector to be able to adapt to the digitalization of the growing education system. The challenges of the 5.0 industrial revolution era need to be carefully packaged and prepared, so that they will be in line with developments. In facing this challenge, it is necessary to strengthen character education to be able to shape the morals of students and to counteract the negative impacts it causes.
To achieve the expected character education goals, the right strategy is needed so that the achievement is more directed and effective. To build good character, the strategies used can not only improve cognitive aspects, but all dimensions such as spiritual, emotional, social, creativity, and motor must also be developed in a focused and structured manner.

According to Maragustam in his book entitled Philosophy of Islamic Education Towards the Formation of Character in Facing Global Flow, that a strategy to form human character requires six pillars. The six pillars are a complete circle which can be taught sequentially or not. The seven pillars are as follows:

\subsubsection{Good habituation and culture}

According to Ibrahim Alfikiy quoted by Maragustam, habits are thoughts that a person creates in his mind, which is then linked to feelings and repeated until the mind believes them to be part of his behavior. The law of habituation goes through six stages, namely:

1) Thinking, someone thinks and knows the values given, then pays attention, and concentrates on these values.

2) Recording, once the values are received, his brain will record. His brain then opens a file similar to that thought and connects with other thoughts, of the same type or which are considered useful for him.

3) Repetition is that someone decides to repeat the good values with the same feeling.

4) Storage, because the recording is done repeatedly of the behavior of the values that entered earlier, the mind becomes stronger.

5) Repetition, whether we realize it or not, a person repeats the behavior of the good values that are stored strongly in his subconscious mind. 
6) Habits become characters, because of the continuous repetition of good values and the stages above that are passed, human reason believes that these habits are the most important part of behavior [7].

With the habituation method character will be formed even though it requires a relatively long and continuous process. This is in line with the sentence which says: "People can because they are used to it", another sentence also says: "First we form habits, then those habits shape us". In addition, habituation is directed at cultivating certain activities so that they become patterned or systemized activities.

\subsubsection{Learning the good things (moral knowing)}

Good habits that someone has done or good things that have not been done, must be given an understanding and knowledge of the value of benefits, rationalization and consequences of good values done. Thus, a person tries to know, understand, realize and think logically about the meaning of a good value and behavior then deepen it and live it. Then these good values turn into intrinsic power that is engrained in a person [7]

\subsubsection{Moral Feeling and loving: feel and love the good}

The birth of moral loving begins with a mindset. A positive mindset towards the values of kindness will benefit from that good behavior. If someone has felt the value of the benefits of doing good things, it will generate a sense of love and affection. If he loves a good thing, then his whole self will sacrifice for the sake of doing that.[7] Consciously thinking and good knowledge will influence and will grow a sense of love and affection. The feeling of love for goodness becomes a power and engine that can make people always want to do good even more than just an obligation even though they have to sacrifice both life and property.

\subsubsection{Moral Acting (good action)}

Through habituation, then thinking knowledge of goodness, continuing to feel the love of that kindness and then the act of experiencing kindness, which in turn forms character. Actions of kindness are based on knowledge, awareness, freedom, and love which will form deposits of experience [7]. From the sediment it will be imprinted in the subconscious mind and so on into character.

\subsubsection{Exemplary (moral model) from the surrounding environment}

Exemplary in education is the most convincing method of influencing its success in preparing and shaping children in moral, spiritual and social terms [17]. This is because educators are the best examples in the eyes of children, who will be imitated in their actions, and their manners, consciously or not, even imprinted in and in the feelings of a description of these learners, both words or deeds, both material and spiritual, whether known or not known.

In educating character, a figure who is a model is needed. The model can be found by children in the surrounding environment, the closer the model is to the child, the easier and more effective the character education is. Children need real examples, not examples written in books. This is in line with Berk's opinion quoted by Siti Masganti [18] moral behavior is obtained in the same way as other responses, namely through modeling and reinforcement. Through modeling learning (exemplary) will occur internalization of various moral, prosocial behavior and other rules for good action. According to the Social Learning Theory quoted by Nurchaili,[19] human behavior is obtained through model observation, from observing other people, forming new ideas and behaviors, and finally being used as a direction for action.

Children learn more from what they see. Verbamovent exempla trahunt. While words can move people, example can move more hearts. For this reason character education is actually more of a demand, especially for educators themselves. This is because good knowledge of values will not be credible when the children have never encountered such neat normative theoretical ideas in their practical life either at home or at school [8].

\subsubsection{Repent (return) to Allah SWT after making a mistake}

In essence, repentance is returning to Allah SWT after making a mistake. Nasuha repentance is repenting of the sins / mistakes he has committed at this time and is sorry for the sins he has committed in the past and promises not to do them again in the future and is determined to do good in the future [7]. Repentance will form awareness of the nature of life, the purpose of life, give birth to optimism, virtue, values obtained from various actions, benefits and emptiness of actions, etc. in such a way that a person is brought forward to take action in a new paradigm and new characters in the days to come.

In addition to the strategies above, in an effort to instill character for the generation in the era of society 5.0 , it must be noted that not only teachers are at the forefront of realizing these goals, but families and the community are involved in realizing them. It can't be if only one of them plays a role, because all influence each other. 
The character education process is based on a psychological totality that includes all the potential of the human individual (cognitive, affective, psychomotor) and the function of the socio-cultural totality in the context of interactions in the family, educational unit, and society.

This is what is then called the three education center, namely the family (parents), schools and the community. The three education centers must be in line and always go hand in hand in carrying out the educational process. In other words, the vision and mission of the three must be the same, or at least be harmonized and synergized so that one another can monitor, control, and evaluate each other's activities. With the existence of synchronization, the communication that exists becomes smooth [20].

\subsubsection{Revitalizing the Role of Parents}

Every parent wants their child to have good character. In reality, parents are faced with several challenges in educating children of this generation in the era of society 5.0. In the era of society 5.0, children are easily connected to all corners of the world online. They also have ample opportunity to obtain information. This generation also tends to want to achieve something quickly and instantly because they are used to the ease of technology.

Parents play an important role in shaping the character of the generation in the era of society 5.0. This is as stated by Effendi that parents are the first and foremost educators for their children, in all areas of both cognitive, value and moral that apply in society [21]. The efforts that parents can do include creating a conducive environment. That way, the generation of the 5.0 society era will grow into a person with character if they can grow in an environment with character too. So that the nature of a child who is born into this world can develop optimally [22].

\subsubsection{Strengthening Character Education in Schools}

In this era of society 5.0 , character education is an important part of creating qualified humans. But in reality, the implementation of character education is not as easy as it says. In order to realize character-based education, it is of course not only the responsibility of the family but also the responsibility of various parties, especially government institutions through formal educational institutions.

Teachers have an important role in the process of forming student character. Teachers are not only able to transfer knowledge, but also able to instill the values that children need to face challenges in the future. The teacher must have intellectual, emotional and spiritual abilities so that the teacher is able to open the eyes of the students to learn about goodness and implement it.
There are several things that schools and teachers can do in instilling character effectively, for example, first the teacher must be a good role model. The teacher's example is the key to success in preparing and forming good character in children. Second, schools must take advantage of social media to carry out the educational process. This will be very effective in reducing the negative impact of disseminating information through social media. Third, implementing a flexible and open education process and adapting to every change in the era of society 5.0 .

\subsubsection{Building a Character Environment}

Character is influenced by heredity (heredity). The behavior of children is often not far from their parents. However, character is also influenced by the environment. The environment is very influential on the character development of the community era generation 5.0. Children who are in a good environment tend to behave well, and vice versa, children who are in a bad environment will also behave badly. Character refers to a series of attitudes, behaviors, motivations, and skills.

This is where the role of family, school and the environment will determine the character formation of generations in the era of society 5.0 for a better life in the future. By building an environment with character, children will grow into intelligent and character personalities so that the nature of every child who is born holy can develop optimally [23].

\section{CONCLUSION}

The character education process is based on a psychological totality that includes all the potential of the human individual (cognitive, affective, psychomotor) and the function of the socio-cultural totality in the context of interactions in the family, educational unit, and society. The strategy of building character education in era of society 5.0 can be by revitalizing the role of parents, strengthening character education in schools, and building a character environment. This is what is then called the teducation center, namely the family (parents), schools and the community. The three education centers must be in line and always go hand in hand in carrying out the educational process. In other words, the vision and mission of the three must be the same, or at least be harmonized and synergized so that one another can monitor, control, and evaluate each other's activities.

\section{REFERENCES}

[1] N. Indramawan, A., \& Hafidhoh, "Pendidikan Karakter Sebagai Upaya Meningkatkan Semangat Belajar," Pros. Semdikjar, vol. 3, no. Pendidikan Karakter, 2019. 
[2] J. P. Subagyo, Metode Penelitian Dalam Teori Dan Praktek. Jakarta: Rineka Cipta., 1991.

[3] C. M. Nazir, Rineka Cipta. Jakarta: Ghalia Indonesia, 1988.

[4] S. Arikunto, Prosedur Penelitian Suatu Pendekatan Praktik. Jakarta: RinekaCipta, 2006.

[5] D. Y. Khan, Pendidikan Karakter Berbasis Potensi Diri. Yogyakarta: Pelangi Publishing, 2010.

[6] D. A. Abdul Majid, Pendidikan Karakter Perspektif Islam. Bandung: Remaja Rosdakarya, 2011.

[7] Maragustam Siregar, Filsafat Pendidikan Islam Menuju Pembentukan Karakter Menghadapi Arus Global. Yogyakarta: Nuha Litera, 2010.

[8] Doni Koesoema A, Pendidikan Karakter: Strategi Mendidik Anak di Zaman Global. Jakarta: PT Grasindo, 2007.

[9] Adang Hambali dan Bambang Q-Aness, Pendidikan Karakter Perspektif Islam. Bandung: Simbiosa Rekatama Media, 2008.

[10] Kementerian Pendidikan Nasional, Pengembangan Pendidikan Budaya dan Karakter Bangsa; Pedoman Sekolah. Jakarta: Badan Penelitian dan Pengembangan Pusat Kurikulum Kemendiknas, 2010.

[11] Robingatul Mutmainnah, Metode Pendidikan Karakter Dalam Pendidikan Islam. Yogyakarta: Idea Press, 2013.

[12] Thomas Lickona, Pendidikan Karakter: Panduan Lengkap Mendidik Siswa menjadi Pintar dan Baik. Bandung: Nusa Media, 2013.
[13] E. Mulyasa, Manajemen Pendidikan Karakter. PT. Bumi Aksara: PT. Bumi Aksara, 2011.

[14] J. P. Dharma Kesuma, Cepi Triatna, Pendidikan Karakter; Kajian Teori dan Praktik di Sekolah. Bandung: Remaja Rosdakarya, 2011.

[15] Ahmad D Marimba, Pengantar Filsafat Pendidikan. Bandung: Al-Ma'arif, 1974.

[16] Muchlas Samani dan Haryanto, Konsep dan Model Pendidikan Karakter. Bandung: Remaja Rosdakarya, 2011.

[17] Nashih Ulwan, Tarbiyatul Al-Aulad Fi Al-Islam. Semarang: As-Syifa', 1993.

[18] Siti Masganti, “Optimalisasi Kompetensi Moral Anak Usia Dini,” J. Pendidik. Dan Kebud., vol. 6, 2010 .

[19] Nurchaili, "Membentuk Karakter Siswa Melalui Keteladanan Guru" dalam Jurnal Pendidikan Dan Kebudayaan,” J. Pendidik. Dan Kebud., vol. 16, no. Pendidikan Karakter, 2010.

[20] Hasbullah, Dasar-dasar Ilmu Pendidikan. Jakarta: Rajawali Press, 2012.

[21] W. A. T. \& B. C. H. Suratman Effendi, Fungsi Keluarga Dalam Meningkatkan Kualitas Sumber Daya Manusia. Jambi: Departemen Pendidikan dan Kebudayan, 1995.

[22] Ratna Megawangi, Pendidikan Karakter. Cimanggis: Indonesia Heritage Foundation, 2007.

[23] Zainul Miftah, Implementasi Pendidikan Karakter Melalui Bimbingan dan Konseling. Surabaya: Gena Pratama Pustaka, 2011. 